Tropical Journal of Pharmaceutical Research, August 2009; 8 (4): 371-375

(C) Pharmacotherapy Group,

Faculty of Pharmacy, University of Benin,

Benin City, 300001 Nigeria.

All rights reserved.

Research Article

Available online at http://www.tjpr.org

\title{
Antimicrobial Activity of the Leaves of Endemic Stachys pseudopinardii in Turkey
}

\section{G Dulger* and C Aki}

Department of Biology, Faculty of Science and Arts, Canakkale Onsekiz Mart University, 17100 Canakkale, Turkey

\begin{abstract}
Purpose: The ethanol extract of the leaves of Stachys pseudopinardii R. Bhattacharjee and Hub.-Mor. (Lamiaceae) were investigated for their antimicrobial activities.

Methods: The antimicrobial activity of the leaf extract of the plant was tested against Bacillus subtilis ATCC 6633, Bacillus cereus ATCC 7064, Staphylococcus aureus ATCC 6538P, Escherichia coli ATCC 10538, Proteus vulgaris ATCC 6899, Salmonella typhimurium CCM 5445 and Pseudomonas aeruginosa ATCC 27853, as well as Candida albicans ATCC 10239, Debaryomyces hansenii DSM 70238, Kluyveromyces fragilis ATCC 8608 and Rhodotorula rubra DSM 70403, by disc diffusion and microdilution methods. Selected antibacterial agents (penicillin, tobramycin and ampicillin) and antifungal agents (nystatin, clotrimazole and ketoconazole) antibiotics were used as positive reference standards in the tests.

Results: The extracts showed strong antibacterial activity against Bacillus cereus ATCC 7064, with an inhibition zone of $25.0 \mathrm{~mm}$, and minimum inhibitory concentration (MIC) and minimum bactericidal concentration (MBC) of 16 and $32 \mu \mathrm{g} / \mathrm{mL}$, respectively. Debaryomyces hansenii DSM 70238 was among the most susceptible of the yeast cultures, with an inhibition zone of $17.0 \mathrm{~mm}$ and MIC and minimum fungicidal concentration (MFC) of 32 and $32 \mu \mathrm{g} / \mathrm{mL}$, respectively. The extract exhibited moderate activity against the other test microorganisms.

Conclusion: The results demonstrate that the ethanol extract of the leaves of Stachys pseudopinardii has significant antimicrobial activity and suggest that it may be useful in the treatment of infections.
\end{abstract}

Key words: Stachys pseudopinardii, ethanol extract, antimicrobial activity, MIC, MBC, MFC 


\section{INTRODUCTION}

Medicinal plants have been known for their healing or disease-curing qualities for centuries. Stachys species have been reported in folk medicine to treat genital tumors, sclerosis of the spleen, inflammatory tumors and cancerous ulcers ${ }^{1}$. Whole plant or leaves of this species are used in phytotherapy and said to possess sedative, antispasmodic, diuretic and emmenagogue activities when used as a tea ${ }^{2}$. Some Stachys species are used as a tonic and for stomach ailments in Anatolia ${ }^{3}$.

Stachys pseudopinardii R. Bhattacharjee \& Hub.-Mor. (Lamiaceae) is endemic to Turkey ${ }^{4}$. A bibliographical survey showed that there are no reports on the antimicrobial activity of this plant. Therefore, the aim of this work was to evaluate the antimicrobial activity of Stachys pseudopinardii which grows wild in Turkey.

\section{MATERIALS AND METHODS}

\section{Plant material}

The plant material was collected from Icel, Turkey in July and August, 2008. A voucher specimen (voucher number GD56) of the plant was deposited in the Biology Department of Canakkale Onsekiz Mart University following identification by Ersin Karabacak of the same Department.

\section{Preparation of extracts}

The leaves of the plant were dried in an oven at $40{ }^{\circ} \mathrm{C}$ for $12 \mathrm{~h}$ and powdered. Each dry powdered plant material $(20 \mathrm{~g})$ was extracted with $150 \mathrm{~mL}$ of $95 \%$ ethanol (Merck, Darmstadt, Germany) for $24 \mathrm{~h}$ using a Soxhlet extractor. The extract was filtered with Whatman filter paper no.1, and the filtrate was evaporated under vacuum in a rotary evaporator at $55{ }^{\circ} \mathrm{C}$. The extract yield obtained was $12.4 \%$. The dry extract, which was sticky and black, was stored in labeled sterile screw-capped bottles at $-20^{\circ} \mathrm{C}$ pending use. Prior to testing, $2 \mathrm{~g}$ was dissolved in 0.4 $\mathrm{L}$ of dimethyl sulfoxide (DMSO) $(5 \mathrm{mg} / \mathrm{mL})$.

\section{Test microorganisms}

In vitro antimicrobial studies were carried out on seven bacterial strains (Bacillus subtilis ATCC 6633, Bacillus cereus ATCC 7064, Staphylococcus aureus ATCC 6538P, Escherichia coli ATCC 10538, Proteus vulgaris ATCC 6899, Salmonella typhimurium CCM 5445 and Pseudomonas aeruginosa ATCC 27853) and four yeast strains (Candida albicans ATCC 10239, Debaryomyces hansenii DSM 70238, Kluyveromyces fragilis ATCC 8608 and Rhodotorula rubra DSM 70403). They were all obtained from the Microbiology Research Laboratory, Department of Biology, Canakkale Onsekiz Mart University, Turkey.

\section{Disc diffusion method}

The paper disc diffusion method was employed $^{5}$. Sterile $6 \mathrm{~mm}$ disc filter paper disc (Schleicher \& Schul, No. 2668, Dassel, Germany) were impregnated with $50 \mu \mathrm{L}$ of the plant extract. The bacterial cultures were inoculated on Nutrient Broth (Oxoid) and incubated for $24 \mathrm{~h}$ at $37 \pm 0.1{ }^{\circ} \mathrm{C}$, while the yeast cultures were inoculated on Malt Extract Broth (Oxoid) and incubated for $48 \mathrm{~h}$ at $28.0 \pm 0.1{ }^{\circ} \mathrm{C}$. Adequate amounts of Mueller Hilton Agar (Oxoid) were dispensed into sterile plates and allowed to solidify under aseptic conditions. The counts of bacterial and yeast cultures were adjusted to yield $10^{7}$ $-10^{8} \mathrm{~mL}^{-1}$ and $10^{5}-10^{6} \mathrm{~mL}^{-1}$, respectively, using the standard McFarland counting method. The test microorganisms $(0.1 \mathrm{~mL})$ were inoculated with a sterile swab on the surface of appropriate solid medium in plates. The agar plates inoculated with the test microorganisms were incubated for $1 \mathrm{~h}$ before placing the extract impregnated paper disc on the plates. The bacterial plates were incubated at $37 \pm 0.1{ }^{\circ} \mathrm{C}$ for $24 \mathrm{~h}$ while yeast plates were incubated at $28 \pm 0.1^{\circ} \mathrm{C}$ for $48 \mathrm{~h}$. After incubation, all plates were observed for zones of growth inhibition and the diameter of 
these zones was measured in millimetres. All tests were performed under sterile conditions in duplicate and repeated three times. Penicillin $(10 \mu \mathrm{g} / \mathrm{disc})$, tobramycin discs (10 $\mu \mathrm{g} /$ disc), ampicillin (20 $\mu \mathrm{g} / \mathrm{disc})$, nystatin (30 $\mu \mathrm{g} / \mathrm{disc})$, clotrimazole $(30 \mu \mathrm{g} / \mathrm{disc})$ and ketoconazole $(20 \mu \mathrm{g} / \mathrm{disc})$ discs were used as positive controls.

\section{Microdilution method}

Determination of the minimum inhibitory concentration (MIC) was carried out according to the method described by Zgoda and Porter, with some modifications ${ }^{6}$. A dilution series of the extract, ranging from 10 to $0.5 \mathrm{mg} / \mathrm{mL}$, were prepared and then transferred to the broth in 96-well microtitre plates. The final concentrations were in the range 1000 to $50 \mu \mathrm{g} / \mathrm{mL}$ in the medium. Before inoculation of the test organisms, the bacterial and yeast strains were adjusted to $0.5 \mathrm{McF}$ arland and diluted 1:1000 in Mueller Hinton Broth (Oxoid) and Malt Extract Broth (Oxoid), respectively. The plates were incubated at $35{ }^{\circ} \mathrm{C}$ for $18-24 \mathrm{~h}$ for bacteria and $30{ }^{\circ} \mathrm{C}$ for $48 \mathrm{~h}$ for the yeast cultures. All the tests were performed in broth and repeated twice. While the MIC values of the extracts were defined as the lowest concentration that showed no growth, minimum bactericidal concentration (MBC) and minimum fungicidal concentration (MFC) were determined by plating samples from clear wells onto Mueller Hinton Agar and Malt Extract Agar, respectively. MBC and MFC were defined as the lowest concentration yielding negative subculture.

Ampicillin and streptomycin were used as the standard antibacterial agents, while nystatin was used as the standard antifungal agent. Their dilutions ranged from 128.0 to 0.25 $\mu \mathrm{g} / \mathrm{mL}$ concentrations in microtitre plates.

\section{RESULTS}

The antimicrobial activities of Stachys pseudopinardii extracts against the test microorganisms examined in this study were qualitatively and quantitatively assessed by inhibition zone, MIC, MBC and MFC. The results are shown in Tables 1 and 2 . The extract of $S$. pseudopinardii exhibited strong antimicrobial effects against the test microorganisms, with inhibition zones ranging from 6 to $25 \mathrm{~mm}$. Notably, B. subtilis was more susceptible to the extract (inhibition zone: $25.0 \mathrm{~mm}$ ) compared to the standard antibacterials, ampicillin and tobramycin, and penicillin whose inhibition zones ranged from $13-18 \mathrm{~mm}$. Similarly, the extract showed higher antibacterial activity against $S$. aureus, $P$. aeruginosa and Proteus vulgaris than some of the standard antibiotics. The antifungal effect of the extract against $C$. albicans and $K$. fragilis was equivalent to those of the standard antifungal agents, nystatin and ketoconazole, respectively. $D$. hansenii was more susceptible to the extract than the standard antifungals, except clotrimazole.

In the microdilution test, the lowest MICs and MBCs of the extract were 16 and $32 \mu \mathrm{g} / \mathrm{mL}$, respectively, against $B$. cereus, followed by $D$. hansenii and $K$. fragilis, with $\mathrm{MIC} / \mathrm{MBC}$ of $32 / 32$ and $64 />128 \mu \mathrm{g} / \mathrm{mL}$, respectively. The extracts showed weak antimicrobial avtivity against the other test microorganisms with $\mathrm{MIC} / \mathrm{MBC}$ ranging from $1000 / 1000$ to $250 / 500$ $\mu \mathrm{g} / \mathrm{mL}$. These values were well below those of the standards.

\section{DISCUSSION}

Ethanol was observed as the best solvent for extracting antimicrobial substances from some plants in a previous study ${ }^{7}$. It is likely that the concentration of extract used in the test may correlate with the activity of its chemical components.

To the best of our knowledge, there are no reports of the antimicrobial activity of Stachys pseudopinardii. Furthermore, investigations of antimicrobial activity of the other Stachys species are few. In previous studies, the antimicrobial activity of some endemic Stachys species - $S$. sivasica, $S$. 
Table 1: Antimicrobial activity of the ethanol extract of S. pseudopinardii

\begin{tabular}{|c|c|c|c|c|c|c|c|}
\hline \multirow{3}{*}{ Microorganism } & \multicolumn{7}{|c|}{ Diameter of zone of inhibition $(\mathrm{mm})^{\mathrm{a}}$} \\
\hline & \multirow{2}{*}{$\begin{array}{l}\text { Extract } \\
(\mu \mathrm{g} / \mathrm{mL})\end{array}$} & \multicolumn{6}{|c|}{ Standard } \\
\hline & & $P$ & AMP & TOB & NYS & KETO & CLT \\
\hline Bacillus subtilis & 11.0 & 14.0 & 12.0 & 24.0 & $\mathrm{Nt}$ & $\mathrm{Nt}$ & $\mathrm{Nt}$ \\
\hline Bacillus cereus & 25.0 & 13.0 & 16.0 & 18.0 & $\mathrm{Nt}$ & $\mathrm{Nt}$ & $\mathrm{Nt}$ \\
\hline Escherichia coli & 6.0 & 16.0 & 14.0 & 10.0 & $\mathrm{Nt}$ & $\mathrm{Nt}$ & $\mathrm{Nt}$ \\
\hline Stapylococcus aureus & 13.0 & 23.0 & 16.0 & 8.0 & $\mathrm{Nt}$ & $\mathrm{Nt}$ & $\mathrm{Nt}$ \\
\hline Pseudomonas & 11.0 & 8.0 & 10.0 & 12.0 & $\mathrm{Nt}$ & $\mathrm{Nt}$ & $\mathrm{Nt}$ \\
\hline \multicolumn{8}{|l|}{ aeruginosa } \\
\hline Proteus vulgaris & 14.0 & 10.0 & 16.0 & 13.0 & $\mathrm{Nt}$ & $\mathrm{Nt}$ & $\mathrm{Nt}$ \\
\hline Salmonella typhimurium & 10.0 & 13.0 & 13.0 & 10.0 & $\mathrm{Nt}$ & $\mathrm{Nt}$ & $\mathrm{Nt}$ \\
\hline Candida albicans & 15.0 & $\mathrm{Nt}$ & $\mathrm{Nt}$ & $\mathrm{Nt}$ & 20.0 & 21.0 & 15.0 \\
\hline Debaryomyces hansenii & 17.0 & $\mathrm{Nt}$ & $\mathrm{Nt}$ & $\mathrm{Nt}$ & 16.0 & 14.0 & 20.0 \\
\hline Kluyveromyces fragilis & 16.0 & $\mathrm{Nt}$ & $\mathrm{Nt}$ & $\mathrm{Nt}$ & 18.0 & 16.0 & 18.0 \\
\hline Rhodotorula rubra & 6.0 & $\mathrm{Nt}$ & $\mathrm{Nt}$ & $\mathrm{Nt}$ & 18.0 & 22.0 & 16.0 \\
\hline
\end{tabular}

${ }^{a} Z$ Zone of inhibition, including the diameter of the filter disc $(6.0 \mathrm{~mm})$; mean value of three independent experiments; $N t=$ not tested; $P=$ penicillin $(10 \mu \mathrm{g} /$ disc $) ; T O B=$ tobramycin discs $(10 \mu \mathrm{g} / \mathrm{disc}) ; A M P=$ ampicillin $(20 \mu \mathrm{g} / \mathrm{disc}) ; \mathrm{NYS}=$ nystatin discs $(30 \mu \mathrm{g} / \mathrm{disc}) ; \mathrm{KETO}=$ ketoconazole $(20 \mu \mathrm{g} / \mathrm{disc}) ; \mathrm{CLO}=$ clotrimazole (30 $\mu \mathrm{g} / \mathrm{disc})$.

Table 2: Minimum inhibitory concentration (MIC) of the ethanol extract of S. pseudopinardii

\begin{tabular}{|c|c|c|c|c|}
\hline \multirow{3}{*}{ Microorganism } & \multicolumn{4}{|c|}{ MIC (MBC or MFC) } \\
\hline & \multirow{2}{*}{$\begin{array}{l}\text { Extract } \\
(\mu \mathrm{g} / \mathrm{mL})\end{array}$} & \multicolumn{3}{|c|}{ Standard } \\
\hline & & ST & AMP & NYS \\
\hline Bacillus subtilis & $500(>1000)$ & $0.5(0.5)$ & $0.5(2.0)$ & $\mathrm{Nt}$ \\
\hline Bacillus cereus & $16(32)$ & $4.0(4.0)$ & $8.0(8.0)$ & $\mathrm{Nt}$ \\
\hline Escherichia coli & $1000(1000)$ & $4.0(4.0)$ & 64 (128) & $\mathrm{Nt}$ \\
\hline Stapylococcus aureus & $250(500)$ & $2.0(4.0)$ & $<0.25(0.35)$ & $\mathrm{Nt}$ \\
\hline Pseudomonas aeruginosa & $1000(1000)$ & $1.0(1.0)$ & $16(32)$ & $\mathrm{Nt}$ \\
\hline Proteus vulgaris & $250(500)$ & $8.0(8.0)$ & $0.5(0.5)$ & $\mathrm{Nt}$ \\
\hline Salmonella typhimurium & $1000(1000)$ & $16(32)$ & $1.0(4.0)$ & $\mathrm{Nt}$ \\
\hline Candida albicans & $250(500)$ & $\mathrm{Nt}$ & $\mathrm{Nt}$ & $8.0(16)$ \\
\hline Debaryomyces hansenii & $32(32)$ & $\mathrm{Nt}$ & $\mathrm{Nt}$ & $16(32)$ \\
\hline Kluyveromyces fragilis & $64(>128)$ & $\mathrm{Nt}$ & $\mathrm{Nt}$ & $16(16)$ \\
\hline Rhodotorula rubra & $1000(1000)$ & $\mathrm{Nt}$ & $\mathrm{Nt}$ & $16(16)$ \\
\hline
\end{tabular}

$N t=$ not tested $; S T=$ streptomycin; $A M P=$ mpicillin; $N Y S=$ nystatin

anumurensis, S. cydnia, S. aleurites and $S$. pinardii - was reported. The methanol extracts of Stachys species were effective only against bacteria ${ }^{8-9}$. In another study, the ethanol extract of $S$. byzantina was found not to be effective against $C$ albicans strains ${ }^{10}$. However, the essential oil of this plant showed anti-Candida activity. The antimicrobial activity of the methanol extracts of Stachys byzantina, $S$. inflata, $S$. lavandulifolia and $S$. laxa were studied against some bacteria and $C$. albicans by Saeedi et $\mathrm{al}^{11}$. The extracts were more active against Gram-positive bacteria. The extracts, however, did not show any antifungal activity. In contrast, the essential oil of $S$. plumosa exhibited antimicrobial activity against bacteria and two C. albicans strains ${ }^{12}$. In another work, the essential oils of eight Stachys species (S. alopecuros, S. scardia, 
S. cretica subsp. cretica, S. germanica subsp. heidrichii, $S$. recta, $S$. euboica and $S$. menthifolia were tested for their antimicrobial activity $^{13}$. The essential oil of $S$. scardia was shown to be the most active against both bacteria and fungi. As can be seen from these literature data, the essential oils of Stachys species have antifungal activity against the yeast cultures, especially $C$. albicans, but the antifungal activity was not observed for the leaf extracts. Notably, in this study, the extract of $S$. pseudopinardii demonstrated antimicrobial activity against both bacteria and yeast cultures. The difference between our results and those of other workers may be due to several factors, for example, the intra-specific variability in the production of secondary metabolites. In addition, there may be differences in the extraction protocols used to recover the active metabolites as well as differences in the assay methods.

\section{Phytochemical analyses of Stachys species} have confirmed the occurrence of diterpenes, phenyl ethanoid glycosides, flavanoids and saponines ${ }^{14}$. Flavonoids may be responsible for their antibacterial activity ${ }^{11}$. The results indicate that $S$. pseudopinardii possessed significant activity against both bacteria and yeast cultures. This activity may be indicative of the presence of metabolic toxins or the compounds stated above. Therefore, this plant extract should be analyzed further, as it might contain a yet unknown compound that is effective against pathogens.

\section{CONCLUSION}

This preliminary evaluation indicated that the ethanol leaf extract of Stachys pseudopinardii has significant activity against the test bacterial and fungal strains used. Further studies are necessary to identify the main active constituents.

\section{REFERENCES}

1. Skaltsa $H D$, Lazari $D M$, Chinou IB, Loukis $A E$. Composition and antibacterial activity of the essential oils of Stachys candida and S. chrysantha from Southern Greece. Planta Med 1999; 65: 255-256.

2. Miller LG, Murray WJ. Herbal Medicinals. A Clinician's Guide. Pharmaceutical Products Press: Binghampton, NY, 1998; p. 223.

3. Baytop T. Therapy with Medicinal Plants in TurkeyPast and Present (in Turkish), 2nd ed. Nobel Tip Basimevi: Istanbul, 1999; p. 193.

4. Davis PH. Flora of Turkey and the East Aegean Islands, Vol. 7, Edinburgh University Press: Edinburgh, 1982; p. 238.

5. Collins CM, Lyne PM. Microbiological Methods. Butterworths and Co. Ltd., London, 1987; p. 316.

6. Zgoda JR, Porter JR. A convenient microdilution method for screening natural products against bacteria and fungi. Pharm Biol 2001; 39: 221 225.

7. Jonathan SG, Fasidi 1O. Antimicrobial activities of two Nigerian edible macrofungi, Lycoperdon pusilum and L. giganteum. Afr J Biomed Res 2003; 6: 85-90.

8. Dulger B, Gonuz A. Antimicrobial activity of some endemic Verbascum, Salvia and Stachys. Pharm Biol 2004; 42: 301-304.

9. Dulger B, Ugurlu E, Aki C, Suerdem TB, Camdeviren $A$, Tazeler G. Evolution of antimicrobial activity of some endemic Verbascum, Sideritis and Stachys species from Turkey. Pharm Biol 2005; 43: 270-274.

10. Duarte MCT, Figueira GM, Sartoratto $A$, Rheder VGL, Delarmelina C. Anti-Candida activity of Brazilian medicinal plants. J Ethnopharmacol 2005; 97(2): 305-311.

11. Saeedi M, Morteza-Semnani K, Mahdavi MR, Rahimi F. Antimicrobial studies on Extracts of Four Species of Stachys. Indian J Pharm Sci 2008; 70(3): 403-406.

12. Petrovic S, Ristic M, Milenkovic M, Kukic J, AnticStankovic J, Niketic M. Composition and antimicrobial activity of essential oil of Stachys plumosa Griseb. Flavour Frag J 2005; 21(2): 250-252.

13. Skaltsa $H D$, Demetzos $C$, Lazari D, Sokovic $M$. Essential oil analyses and antimicrobial activity of eight Stachys species from Greece. Phytochemistry 2003; 64(3): 743-752.

14. Khanavi $M$, Sharifzadeh $M$, Hadjiakhoondi $A$, Shafiee A. Phytochemical investigation and anti-inflammatory activity of aerial parts of Stachys byzantina C. Koch. J Ethnopharmocol 2005; 97: 463-468. 